\title{
FIRE AND FLOODS: THE RECOVERY OF HEADWATER STREAM SYSTEMS FOLLOWING HIGH-SEVERITY WILDFIRE
}

\author{
Jackson M. Leonard ${ }^{1 *}$, Hugo A. Magaña ${ }^{2}$, Randy K. Bangert ${ }^{3,4}$, \\ Daniel G. Neary ${ }^{1}$, and Willson L. Montgomery ${ }^{3}$ \\ ${ }^{1}$ USDA Forest Service, Rocky Mountain Research Station, Flagstaff Lab, \\ 2500 South Pine Knoll Drive, Flagstaff, Arizona 86001, USA \\ ${ }^{2}$ USDA Forest Service, North Fork John Day Ranger District, \\ 401 West Main Street, Ukiah, Oregon 97880, USA \\ ${ }^{3}$ Northern Arizona University, Department of Biological Sciences, \\ 617 South Beaver Street, Flagstaff, Arizona 86011, USA \\ ${ }^{4}$ Northern Arizona University, School of Earth Science and Environmental Sustainability, \\ 525 South Beaver Street, Flagstaff, Arizona 86011, USA \\ *Corresponding author: Tel: +1-928-556-2180; e-mail: jleonard@fs.fed.us
}

\begin{abstract}
This study examined the recovery of both physical and biotic characteristics of small $\left(<0.1 \mathrm{~m}^{3} \mathrm{sec}^{-1}\right)$ headwater stream systems impacted by the Dude Fire, which occurred in central Arizona, USA, in 1990. Data collected prior to the fire from 1986 to 1988 was compared to similar data collected at various points after the fire though 2011 in order to assess changes in the geomorphology and macroinvertebrate communities over the 21-year time period. Additionally, several environmental parameters of the impacted streams were compared to neighboring unburned headwater streams in order to determine recovery status. The study hypothesized that the headwater aquatic ecosystems impacted by the Dude Fire have yet to recover to unburned reference conditions. Results show that flooding, which occurred following the fire, resulted in incision in ex-
\end{abstract}

\section{RESUMEN}

Este estudio examina la recuperación de las características físicas y bióticas de pequeños $\left(<0,1 \mathrm{~m}^{3} \mathrm{sec}^{-1}\right)$ sistemas de cabeceras de arroyos impactados por el incendio Dude, ocurrido en el centro de Arizona, EEUU en 1990. Los datos colectados previos al fuego entre 1986 y 1988 fueron comparados con datos similares colectados en varios puntos después del incendio hasta 2011, para determinar cambios en la geomorfología y comunidades de invertebrados en este período de 21 años. Adicionalmente, algunos de los arroyos impactados fueron comparados con sistemas de cabeceras de arroyos vecinos no impactados, para poder determinar el estatus de recuperación. Este estudio sostenía la hipótesis que los sistemas acuáticos de estas cabeceras de cuencas impactadas por el incendio Dude estaban lejos de recuperarse en relación a los sistemas de referencia no impactados. Los resultados muestran que las inundaciones, ocurridas luego del incendio, provocaron incisiones que excedieron los 0,5 $\mathrm{m}$ en algunas transectas hechas en los cauces 
cess of $0.5 \mathrm{~m}$ across some stream transects and is continuing to cause shifts in dominant substrate particle size. Macroinvertebrate richness, diversity, and abundance were altered from prefire conditions up to a decade after the fire. Streamside canopy cover across burned streams remained 28\% lower on average. Lower concentrations of key stream nutrients, including nitrate $\left(\mathrm{NO}_{3}{ }^{-}\right)$and phosphate $\left(\mathrm{PO}_{4}{ }^{3-}\right)$, within impacted streams are still evident. Increases in summer stream temperatures due to the loss of streamside canopy cover continue to have an adverse affect on salmonid habitat. Thus, the process of recovery is closely tied to streamside vegetation and hydrologic disturbance patterns following the fire event, and will extend beyond the 21year time period of this study. de los arroyos, y que continúan causando cambios en los estratos de las partículas dominantes. La riqueza, diversidad y abundancia de macro-invertebrados fue alterada desde las condiciones pre-fuego y hasta 10 años después de su ocurrencia. El dosel de especies que se encuentran a la vera de los arroyos impactados por el fuego se redujo y permaneció un $28 \%$ menos en promedio que en los lugares no impactados. Una menor concentración de nutrientes clave en los arroyos, incluidos nitratos $\left(\mathrm{NO}_{3}^{-}\right)$y fosfatos $\left(\mathrm{PO}_{4}^{3-}\right)$, es todavía evidente. El incremento de la temperatura del agua en los arroyos durante el verano debido a la menor cobertura del dosel de árboles ribereños todavía tiene un efecto adverso en el hábitat de los salmónidos. Esto demuestra que el proceso de recuperación está ligado a la vegetación ribereña y a los patrones de disturbios que siguieron al evento de fuego, y que se extienden más allá de los 21 años que duró este estudio.

Keywords: geomorphology, headwater stream, macroinvertebrate, riparian, wildfire effects

Citation: Leonard, J.M., H.A. Magaña, R.K. Bangert, D.G. Neary, and W.L. Montgomery. 2017. Fire and floods: the recovery of headwater stream systems following high-severity wildfire. Fire Ecology 13(3): 62-84. doi: 10.4996/fireecology.130306284

\section{INTRODUCTION}

Decades of fire suppression during the twentieth century across the American West have led to accumulation of forest fuels (Adams 2013), resulting in larger and more destructive wildfires (Westerling et al. 2006). Human-induced warming of the atmosphere is contributing to this phenomenon (Huntington et al. 2009, Ball et al. 2010, Williams et al. 2010, Kashian et al. 2013). Severe fire events can have profound impacts on the physical and environmental function of aquatic systems (Dunham et al. 2007, Hall and Lombardozzi 2008). These include changes in geomorphology, channel substrate, water temperature, and stream chemistry, among others (Minshall et al. 2001a, Isaak et al. 2010, Rhoades et al.
2011). The influence of alteration of physical habitat on the biotic function of a stream can last for decades (Minshall 2003, Arkle et al. 2010).

Recent population expansion and drought conditions within the American Southwest have put increasing pressure on important aquatic resources (Seager et al. 2007). Often, headwater environments in the region are isolated from downstream habitats. In some instances, stream flow is captured for municipal water supplies or diverted for irrigation purposes, and in other instances, stream flow naturally flows underground due to geologic conditions. These fragmented stream habitats often cannot be colonized by species from downstream sources after disturbance events, which may slow or even prevent natural recovery and 
result in the loss of key habitat functions (Dunham et al. 2003, Dunham et al. 2007).

Habitat and biotic community structure in streams impacted by wildfire are often driven by the degree of impact of the fire and streamflow events that follow (Minshall et al. 2001b, Vieira et al. 2004). Often, flooding events have the potential to influence the timing and volume of sediment yields within streams for decades following a wildfire event (Goode et al. 2012). Due to the increasing severity of wildfires, the stabilization and recovery time of the physical habitat of a stream may also be increasing. Studies have suggested that the recovery process may be curtailed completely if the fire return interval is shorter than the time required for recovery (Arkle et al. 2010).

In addition to physical changes, wildfire events also remove both upland and streamside vegetation, directly influencing biotic communities within aquatic ecosystems (Minshall et al. 1995, Rhoades et al. 2011). Shifts from allochthonous sources to autochthonous sources can result in changes in the entire biotic community within a stream system (Minshall et al. 2001c). Aquatic macroinvertebrate communities are used extensively in the environmental assessment of stream systems (Rosenberg and Resh 1993). Composition of macroinvertebrate communities often reflects changes in streamside vegetation due to fire (Tronstad et al. 2012). They are commonly used to determine overall stream health and biologic productivity due to their relative lack of mobility and associated persistence in the system for extended periods (Davis et al. 2001, Minshall et al. 2001b, Oliver et al. 2012).

In general, macroinvertebrate communities are thought to recover to reference conditions within 10 to15 years following a fire event (Minshall 2003). However, the recovery time may be increasing due to factors such as climate change (Minshall et al. 2001a, Vieira et al. 2004, Rugenski and Minshall 2014). This suggests that our ability to accurately predict the recovery of aquatic communities following wildfire requires further study. This is especially true in the southwestern US, where long-term studies to assess the duration of such effects are rare.

The loss of streamside vegetation can also contribute to the alteration of thermal regimes after wildfire. This in turn influences the recovery, distribution, abundance, growth, and persistence of aquatic species (Eaton and Scheller 1996). Increases in stream temperature after wildfire can adversely affect dissolved oxygen levels within a stream and lead to a loss of habitat for cold-water species (Burton 2005). Elevated temperatures can easily persist for decades after the initial fire event and are exacerbated when severe floods completely eliminate streamside vegetation (Minshall et al. 2001b). Permanent habitat conversion is possible if streamside vegetation does not reestablish (Amaranthus et al. 1989, McKenzie et al. 2004, Dunham et al. 2007). Enhanced by the influence of global warming (Intergovernmental Panel on Climate Change 2014, Cook et al. 2015), the alteration of aquatic thermal regimes may be one of the most influential forces on aquatic ecosystem function following wildfire (Isaak et al. 2010).

The objective of this study was to determine if several important biological and physical parameters impacted by the Dude Fire continue to differ from unburned, reference conditions. Macroinvertebrate data collected prior to the fire, from 1985 to 1988 , were compared with samples collected following the fire, in 2002 and 2011. Changes in channel morphology and channel bedload were also quantified to determine the influence of wildfire-induced hydrologic disturbances. Environmental parameters including water chemistry, stream temperature, and streamside canopy cover, among others, were compared in order to evaluate the long-term recovery process.

This study hypothesized that impacts to specific physical and biological parameters as a result of the Dude Fire have yet to recover when compared to reference conditions even 
after more than 20 years. Assessing long-term impacts is important because the Dude Fire was the first of several much larger landscape-scale, high-severity wildfire events that have struck the region in the last 35 years. Understanding the process of long-term recovery from these events will help improve the management and overall health of these systems.

\section{METHODS}

The study area was located in central Arizona, USA, directly below the Mogollon Rim in the Tonto National Forest (Figure 1). Elevations ranged from $2350 \mathrm{~m}$, where ponderosa pine (Pinus ponderosa Lawson and C. Lawson) predominates, to $1450 \mathrm{~m}$ in the pine-juniper-oak (Pinus spp.-Juniperus spp.-Quercus spp.) zone. Precipitation occurred primarily during the summer monsoons and in the winter as rain and snow. The average annual precipitation for the area was $635 \mathrm{~mm}$. Temperature ranges from $-10^{\circ} \mathrm{C}$ to $32^{\circ} \mathrm{C}$, with an average temperature of $14^{\circ} \mathrm{C}$ (Medina and Royalty 2002). The geology of the study area was a complex lithology of sandstones in the higher elevations and on ridgetops, and Fort Apache limestone in lower elevations (Parker et al. 2005). According to the USDA Terrestrial Ecosystem Survey, the soils are classified as Udic Haplustalfs, fine, mixed, mesic, deep gravelly loams (United States Department of Agriculture 1989).

The headwater streams studied emanate from the base of the Mogollon Rim. This escarpment extends throughout central Arizona into western New Mexico. It defines the southern edge of the Colorado Plateau and serves a major faunal and floristic boundary in

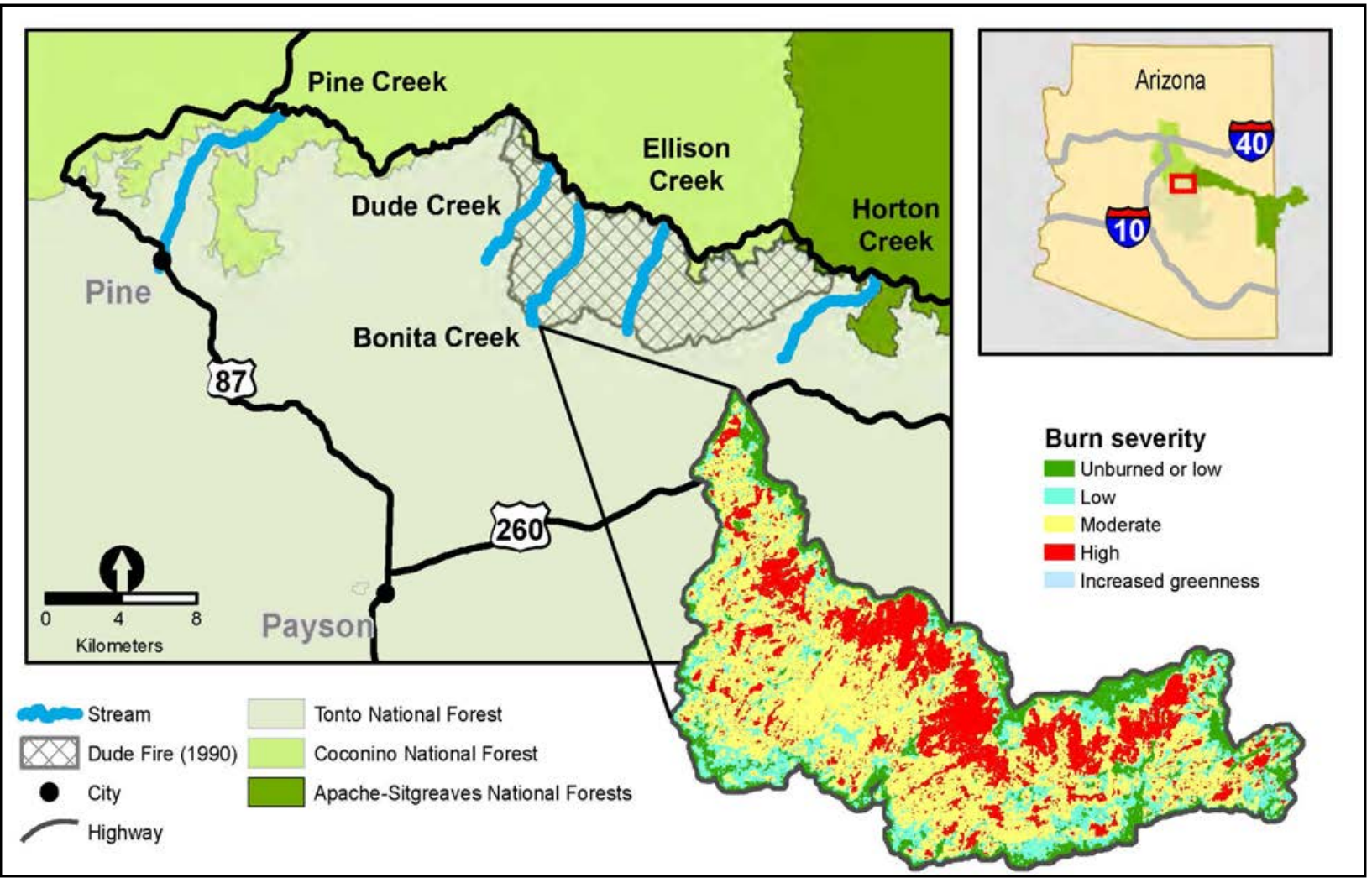

Figure 1. Map of five headwater streams locations included in the study in Tonto National Forest, Arizona, USA. Cross hatching denotes the area affected by the Dude Fire. The burn severity map indicates that areas of highest severity occurred near the points of origin for the three impacted streams. 
the region. A majority of Arizona's perennial stream systems originate above or just below the escarpment. Currently, Arizona receives approximately $21 \%$ of its annual municipal water supply from these systems (http://www. azwater.gov), with the rest being supplied through groundwater pumping or allotments to the Central Arizona Project from the Colorado River.

The Dude Fire began on 25 June 1990, ignited by a lightning strike from a summer storm. Over a 6-day period, the fire consumed approximately 10153 hectares, burning across several headwater stream drainages. At the time, the Dude Fire was considered one of the most destructive wildfires in Arizona history. Post-fire estimates by the US Forest Service classified approximately $70 \%$ of the area burned, including riparian zones, as either moderate or high severity (Ingram et al. 1991). A study conducted in 2005 on the upland areas burned by the fire concluded that conversion from a ponderosa pine-dominated system, to an oak-manzanita (Arctostphylos spp.)-dominated system had occurred, due, in part, to the high severity of the fire (Leonard et al. 2015).

Following the fire, seasonal monsoon storms produced localized flooding events across the burned area, resulting in ash and slurry flows into stream channels. These seasonal storms tend to be high-intensity, shortduration events, and it is relatively common for post-fire debris-ash-slurry flows to occur as a result (Cannon et al. 2008). Biological surveys following these flows concluded that nearly all fish and macroinvertebrate species had been extirpated from the impacted streams (Rinne 1996). Subsequent data taken from a US Geological Survey stream gauge on the main stem of the East Verde River, which drains four of the five creeks in this study, indicated that regional flooding events occurred in 1993 and 1995 (Fuller et al. 1996; Figure 2). These flows resulted in physical alteration of the stream channels within the burned area due to the previous loss of the upper soil horizons and vegetative cover.

\section{Site Selection}

The three first-order streams included in this study-Dude Creek, Bonita Creek, and Ellison Creek-were severely impacted by the Dude Fire and flooding events that followed. Each burned watershed ranged in size from approximately 227 ha to 777 ha. Two nearby unburned first-order streams, Horton Creek and Pine Creek, were used as reference streams because of their proximity and likeness in character to the impacted streams and measured 1029 ha and 1298 ha, respectively (Table 1). All aquatic and terrestrial habitat surveys were within study sites comprised of a $40 \mathrm{~m}$ stream reach based on the minimum length of stream segments that captured at least one riffle, run, and pool habitat (Medina and Royalty 2002). Five transects were established on each stream for a total of 25 transects across burned and reference streams.

\section{Macroinvertebrates}

Macroinvertebrate communities were characterized using richness and abundance data derived from semi-quantitative and qualitative samples from these communities (Moulton et al. 2000). Macroinvertebrate sampling methodology was adopted from pre-fire sampling that collected samples within riffle habitats using a $0.09 \mathrm{~m}^{2}$ Surber sampling frame and hand scraping channel substrate materials within the stream with a stiff bristled brush (Rinne and Medina 1988). Samples were taken at each of five sites per stream within riffle habitats of similar substrate, depth, and velocity. Samples were preserved in $70 \%$ ethanol. The pre-fire samples were collected in the beginning of August in 1985, 1986, 1987, and 1988. Postfire samples were collected in late June and early July of 2002 and 2011. A maximum of 600 individual macroinvertebrates from each sample were identified and enumerated down to the lowest possible taxonomic level and classified into Operational Taxonomic Units based on Cuffney et al. (2007). Functional 


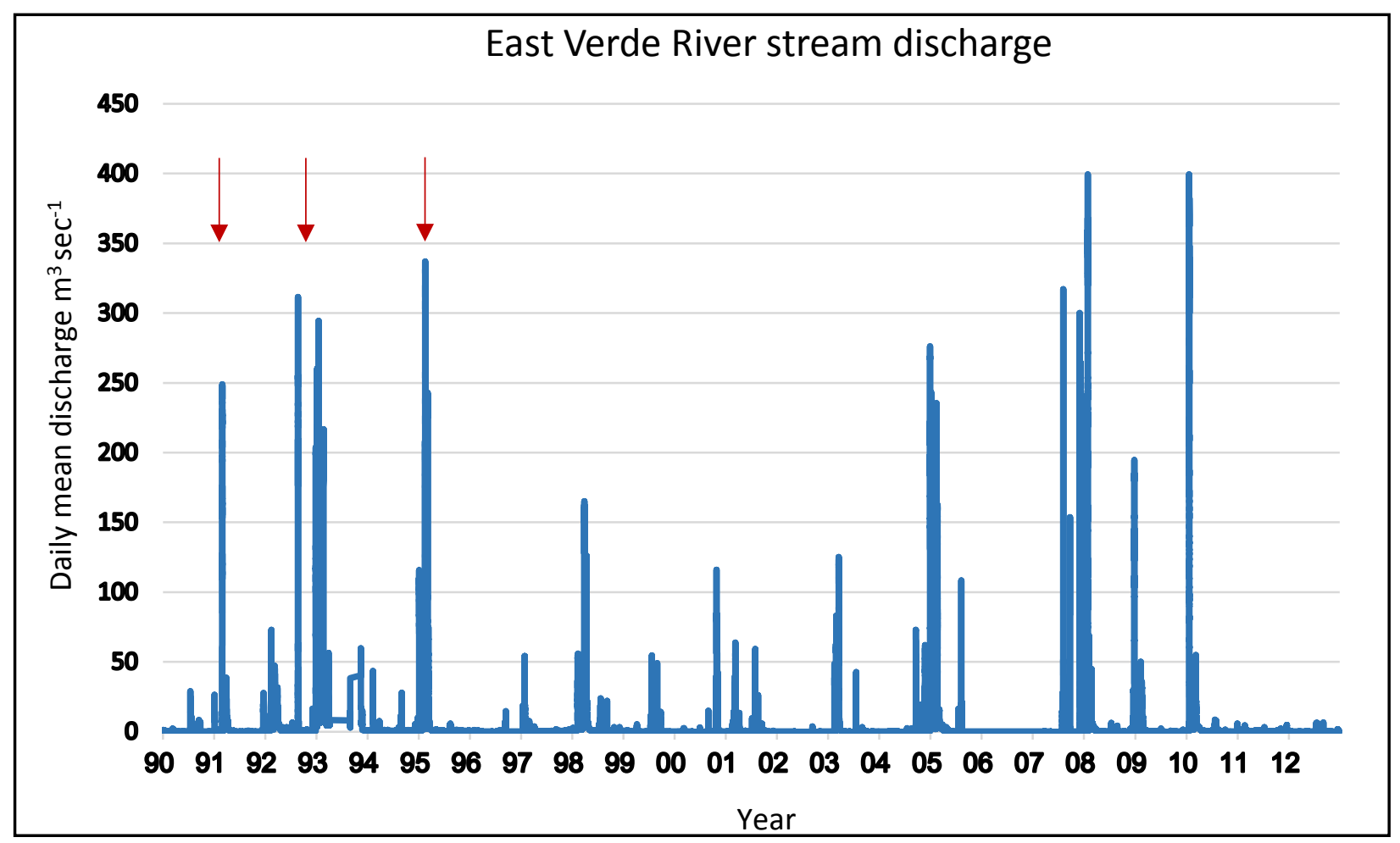

Figure 2. Streamflow data from the East Verde River watershed over the duration of the study. Large regional flooding events occurred in the decade following the fire in 1991, 1993, and 1995. Data courtesy of the US Geological Survey.

Table 1. Descriptive data for each stream in the study in 2011. Point data collected from five sites within each stream was used to calculate an average.

\begin{tabular}{lcccccc}
\hline & \multicolumn{3}{c}{ Burned streams } & & \multicolumn{2}{c}{ Unburned streams } \\
\cline { 2 - 3 } & Bonita & Dude & Ellison & & Horton & Pine \\
\hline Watershed size (ha) & 227 & 487 & 777 & & 1029 & 1298 \\
Average summer flow rate $\left(\mathrm{m}^{3} \mathrm{sec}^{-1}\right)$ & 0.031 & 0.030 & 0.002 & & 0.091 & 0.050 \\
Average slope $(\%)$ & 4.44 & 3.56 & 5.09 & 3.29 & 3.24 \\
Average conductivity $\left(\mu \mathrm{S} \mathrm{cm}^{-1}\right)$ & 157.2 & 181.2 & 141.9 & & 166.4 & 158.2 \\
Average dissolved oxygen $(\%)$ & 81.7 & 83.3 & 78.9 & & 88.8 & 82.4 \\
Average $\mathrm{pH}$ & 8.8 & 8.7 & 8.6 & 8.8 & 8.3 \\
\hline
\end{tabular}

feeding groups were classified by the methods of Cummins and Merritt (2008).

Macroinvertebrate data were compared using analysis of richness, diversity, and evenness. Comparisons of abundance data for key macroinvertebrate orders as well as functional feeding groups were also presented for 2011. It should be noted that the only reference stream measured in 2002 was Pine Creek. We chose to include this data since the information it provides is useful. However, direct comparisons between this year and other years, (e.g., comparisons between 2002 reference and 2002 burned streams, or comparisons between 2002 reference and 1988 reference streams was avoided). For this reason, it is 
difficult to definitively say that trends seen in burned streams in 2002 differed from reference levels; we can only say how they differed from pre-fire levels. The macroinvertebrate sampling conducted in 2011 was used to base final conclusions about community recovery.

\section{Geomorphology}

Physical assessment was conducted on all three of the burned streams in addition to Pine Creek, a reference stream. Establishment of geomorphology transects by the Rocky Mountain Research Station and Tonto National Forest began immediately after the fire on Dude
Creek in July 1990 (Figure 3). The transects were installed just prior to the arrival of the summer monsoon season, making them a measure of pre-fire conditions because the watershed had not received precipitation that would have generated any increased flow events. All stream transects were examined for geomorphic structure using techniques established by the Rosgen Stream Classification Technique (Rosgen 1994). Measurements included assessing channel slope, bankfull discharge, bedload classification, and channel width-to-depth ratio. Survey data were collected using an RL-HA Topcon rotary laser level (Topcon Corp., Tokyo, Japan) with an accuracy of \pm 25
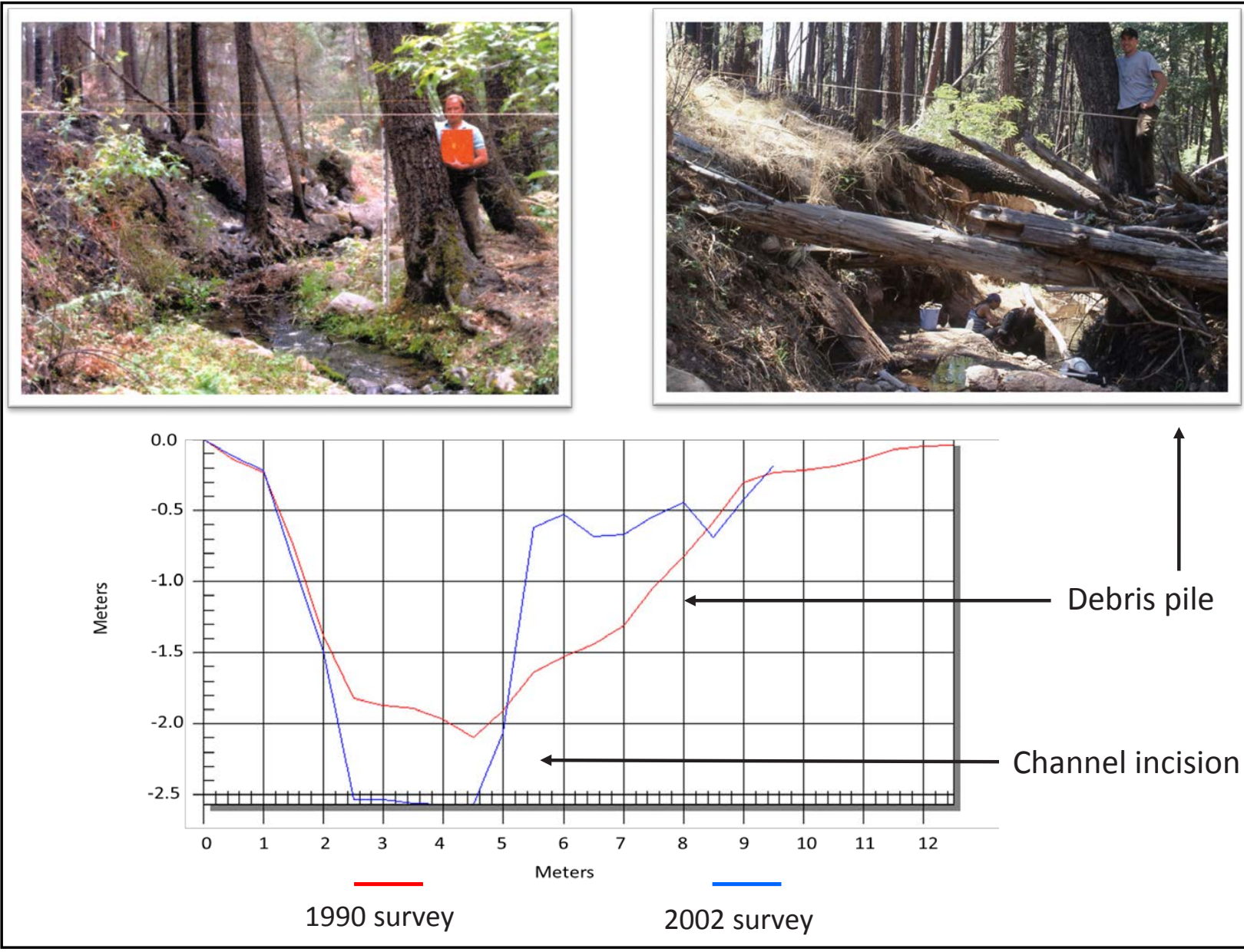

Figure 3. The comparison of Transect 1 of Dude Creek beginning immediately after the fire in July 1990 (left) to the same location in 2002 (right) demonstrates the incision of the stream channel and the accumulation of woody debris following the fire. The associated graph allows for the quantification of the change in area of the stream channel from 1990 (red) to 2002 (blue). 
$\mathrm{cm}$ at $50 \mathrm{~m}$. The cross-channel profile was determined by measuring the vertical displacement across the horizontal transect line. Measurements were taken starting at a reference point $(0 \mathrm{~m})$ and at $1 \mathrm{~m}$ intervals or at intervals that reflected the local topography. A 300-sample pebble count based on the methods developed by Bevenger and King (1995) was also conducted.

\section{Water Sampling}

Water temperature, specific conductance, $\mathrm{pH}$, dissolved oxygen (DO), and percent saturation of DO were measured using a YSI 556 multiprobe (YSI Incorporated, Yellow Springs, Ohio, USA) at each of 5 sampling sites per stream during summer sampling periods. Continuous water temperature measurements were taken every 60 minutes from 28 April to 30 September, 2011, at each stream using HO$\mathrm{BO}^{\mathrm{TM}}$ Pro V2 dataloggers (Onset Computer Corp., Bourne, Massachusetts, USA), with the exception of Bonita Creek, where the datalogger was lost. Water depth and velocity were measured at each sampling location during summer sampling periods using a Rickly USGS top setting wading rod (Rickly Hydrological Co., Inc., Columbus, Ohio, USA) and a Marsh-McBirney pressure sensor (Marsh-McBirney Inc., Frederick, Maryland, USA).

Water samples $(60 \mathrm{ml})$ were collected during May 2011 and 2012 as well as September 2012. Samples were taken in triplicate for water chemistry analysis at three sites per stream, for a total of nine samples per stream, using a grab-sample method. Samples were placed on ice and transported to the lab where analyses were performed using ion chromatography separation and conductivity detection. Samples were run on a Dionex ${ }^{\circledR}$ Ion Chromatography system, with a GP40 gradient pump and an ED40 Electrochemical detector (Dionex Corp., Sunnyvale, California, USA). Cation analyses used a CS12A (4 mm × 250 $\mathrm{mm}$ ) column with $20 \mathrm{mM}$ methanesulfonic acid eluent to determine the concentration of lithium $\left(\mathrm{Li}^{+}\right)$, sodium $\left(\mathrm{Na}^{+}\right)$, ammonium $\left(\mathrm{NH}^{4+}\right)$, potassium $\left(\mathrm{K}^{+}\right)$, magnesium $\left(\mathrm{Mg}^{2+}\right)$, and calcium $\left(\mathrm{Ca}^{2+}\right)$ ions (Dionex 2001). Anion analyses used an IonPac AS4A-SC (4 mm $\times$ $250 \mathrm{~mm}$ ) column with $1.8 \mathrm{mM} \mathrm{Na}_{2} \mathrm{CO}_{3}$ per 1.7 $\mathrm{mM} \mathrm{NaHCO}{ }_{3}$ eluent to determine the concentration of fluoride $\left(\mathrm{F}^{-}\right)$, chloride $\left(\mathrm{Cl}^{-}\right)$, bromide $(\mathrm{Br})$, nitrate $\left(\mathrm{NO}_{3}^{-}\right)$, phosphate $\left(\mathrm{PO}_{4}^{3-}\right)$, and sulfate $\left(\mathrm{SO}_{4}^{2-}\right)$ ions. Methods were adapted from Pfaff (1993).

\section{Benthic Algae Sampling}

Periphyton, sediment, and detritus were collected at the river margin, thalweg, and interstitial spaces of cobble in triplicate from each of five sites on each stream during the summer of 2011. Samples were taken using a sediment corer or grab sample (a single measurement taken at a specific location) and placed in petri dishes. Samples were kept on ice during transport to the lab for analyses. Periphyton and algal samples were analyzed for chlorophyll $a$ using cold methanol extraction and measured fluorometerically (Welschmeyer 1994). Chlorophyll $a$ concentrations $\left(\mathrm{g} \mathrm{cm}^{-2}\right)$ were used as a proxy for algal biomass in each multi-species sample (Welschmeyer 1994).

\section{Canopy Closure}

Canopy closure estimates were obtained using a Spherical Densiometer, Model $\mathrm{C}^{\mathrm{TM}}$ (Forest Densiometers, Bartlesville, Oklahoma, USA). Estimates were taken from each stream $(n=3)$ at the center of the channel along each geomorphology transect during the summer of 2011, after all riparian vegetation had leafed out. The canopy closure observations were made using the methodology based on Strickler (1959).

\section{Analysis}

In order to standardize variation in legacy macroinvertebrate datasets, abundance was standardized to percent abundance by sum- 
ming the total count of individuals in each unique taxa per sample, and dividing it by the total count of individuals for that treatment year. Macroinvertebrate analyses were quantified with Standard Least Squares ANOVA using JMP ${ }^{\mathrm{TM}}$ Pro 10 software (SAS Institute Inc., Cary, North Carolina, USA). Data were quantified into Recognizable Taxonomic Units (Oliver and Beattie 1996) for richness and Shannon's diversity $\left(H^{\prime}\right)$. Percent abundance was quantified for the orders Coleoptera, Diptera, Ephemeroptera, Plecoptera, Trichoptera, and the Ephemeroptera, Plecoptera, and Trichoptera group. We also quantified percent abundance for the functional feeding groups of filterers, gatherers, scrapers, shredders, and predators.

The assumptions for ANOVA were tested with the Shapiro-Wilks test for normality, and Levene's test for equal variance. No data transformations were required. The factors in the richness, Shannon's diversity $\left(H^{\prime}\right)$, and Pielou's evenness $\left(J^{\prime}\right)$ models were burned for the fire effect and pre or post for the pre-fire versus post-fire effect. There were no interaction effects removed from the models. Figures are presented by year, but the analyses were performed on the factors of burned and pre or post. All error bars are standard errors. The comparison in the post-fire (2011) analyses for richness, Shannon's diversity $\left(H^{\prime}\right)$, Pielou's evenness $\left(J^{\prime}\right)$, functional feeding groups, and orders models was between the burned and reference streams for the fire effect. All error bars are standard errors.

A Generalized Linear Mixed Model was used to analyze summer stream temperature. The predictors include stream and a quadratic effect for sequential day. A repeated measures temporal correlation structure was incorporated into the model using a first-order autoregressive structure. Treatment-level comparisons between streams were adjusted using Tukey's method (Kramer 1956). Degrees of freedom were adjusted using the Kenward-Roger method (Kenward and Roger
1997). All analyses were conducted using SAS PROC GLIMMIX in Version 9.4 of the SAS System for Windows. (SAS Institute Inc.)

The software program WinXSPRO was used to analyze and compare all geomorphic cross-sections in the study (Hardy et al. 2005), and produces estimates of cross-sectional change in area (Figure 3).

\section{RESULTS}

\section{Geomorphology}

From 1990 to 1992, comparison of changes in area of the three transects established on Dude Creek averaged $0.07 \mathrm{~m}^{2}$, ranging from $4.3 \mathrm{~m}^{2}$ to $-4.4 \mathrm{~m}^{2}$, suggesting both net loss and retention of sediment. In 1996, additional transects were established on Bonita Creek and the existing transects on Dude and Ellison creeks were re-surveyed. From 1992 to 1996, all transects showed some degree of sediment loss. Transects on Dude Creek were incised by an average of $-5.7 \mathrm{~m}^{2}$, ranging from -11.2 $\mathrm{m}^{2}$ to $-0.8 \mathrm{~m}^{2}$, while the transect on Ellison Creek incised $-2.7 \mathrm{~m}^{2}$.

In 2001, geomorphology sampling was expanded further to include new transects on Pine Creek, an unburned reference creek. Previous transects were re-surveyed on Dude, Bonita, and Ellison creeks. Results from the 1996 to 2001 period show an overall loss of sediment across all transects. Dude Creek incised an average of $-7.9 \mathrm{~m}^{2}$, ranging from 23 $\mathrm{m}^{2}$ to $0 \mathrm{~m}^{2}$; while transects on Ellison Creek were incised an average of $-0.5 \mathrm{~m}^{2}$, ranging from $-2 \mathrm{~m}^{2}$ to $0.6 \mathrm{~m}^{2}$; and transects on Bonita Creek incised and average of $-0.5 \mathrm{~m}^{2}$, ranging from $-1.7 \mathrm{~m}^{2}$ to $-0.1 \mathrm{~m}^{2}$.

Finally, in 2011, transects across all streams were re-surveyed and compared to 2001 surveys. From 2001 to 2011, all streams showed general stability. Transects on Dude Creek aggraded $0.4 \mathrm{~m}^{2}$ on average, ranging from $-2.8 \mathrm{~m}^{2}$ to $3.2 \mathrm{~m}^{2}$; Ellison Creek aggrad- 
ed $2.4 \mathrm{~m}^{2}$ on average, ranging from $0.1 \mathrm{~m}^{2}$ to $6.5 \mathrm{~m}^{2}$; Bonita Creek aggraded $0.03 \mathrm{~m}^{2}$ on average, ranging from $-1.4 \mathrm{~m}^{2}$ to $0.8 \mathrm{~m}^{2}$; and Pine Creek aggraded $1.3 \mathrm{~m}^{2}$ on average, ranging from $-0.2 \mathrm{~m}^{2}$ to $4.2 \mathrm{~m}^{2}$ (Figure 4 ).

Dominant particle size changed from 2001 to 2014 in Dude Creek from silt to boulder or bedrock and, in Ellison Creek, from cobble to silt, indicating instability and change in the makeup of the bedload. Individual comparisons of substrate habitat show that Dude Creek had the highest occurrence of bedrock of any of the burned streams in the study. Conversely, the dominant particle size did not change in Bonita or Pine creeks, an indication of stability in the bedload over this period (Table 2). Along with the geomorphology surveys, the pebble count results demonstrate that the alterations in channel morphology and the destabilization of channel bedload conditions occurred the most within Dude and Ellison creeks following the fire.

\section{Macroinvertebrates.}

Following the fire, species richness and Shannon's diversity increased, on average, from pre-fire conditions to the post-fire conditions (richness: $F_{1,30}, P=0.002$; Shannon's diversity: $F_{1,30}, P=0.001$; respectively; Figure

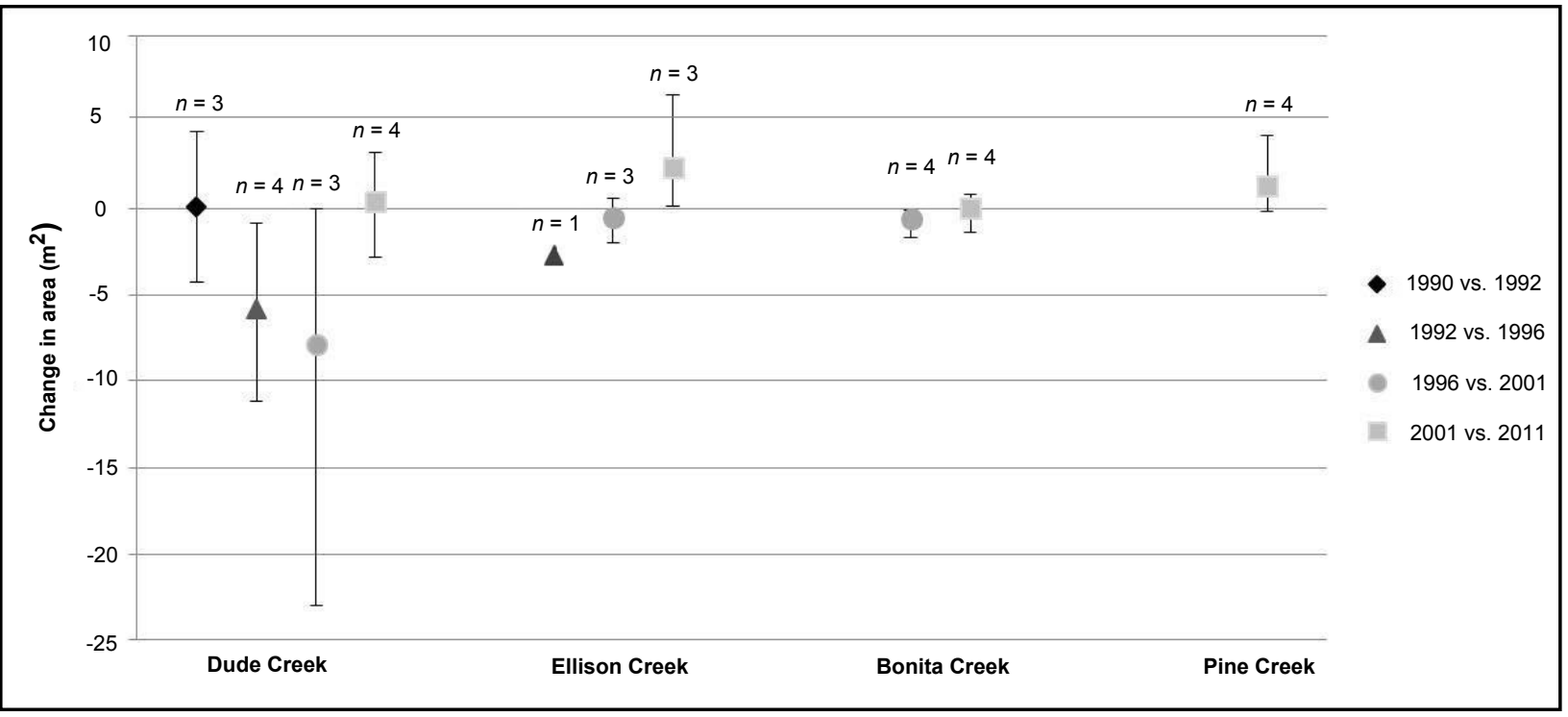

Figure 4. Changes in cross-channel area across the three burned streams within the study and Pine Creek, a reference stream. Total range of data is denoted by error bars and $n$ denotes the number of transects that were compared for each time period. Regional flooding events occurred across the study in the decade following the fire in 1991, 1993, and 1995.

Table 2. Pebble count data comparison between 2001 and 2014 for each burned stream in the study and Pine Creek, a reference.

\begin{tabular}{lccc}
\hline Stream & 2001 dominant particle size $\mathbf{( m m )}$ & 2014 dominant particle size $\mathbf{( m m})$ & Condition \\
\hline Pine & 64 to 95 - cobble & 128 to 191 -cobble & Reference \\
Dude & 0.5 to 0.9 - silt & $>10000$-boulder or bedrock & Burned \\
Bonita & 128 to 191 -cobble & 128 to 191 -cobble & Burned \\
Ellison & 64 to 95 - cobble & 0.5 to 0.9 -silt & Burned \\
\hline
\end{tabular}


5). More specifically, by 2002, the burned streams showed significant increases for richness: $F_{1,13}, P=0.02$; percent mean abundance: $F_{1,13}, P=0.001$; Shannon's diversity: $F_{1,13}, P$ $=0.01$; and evenness: $F_{1,13}, P=0.03$ (Figure 6) when compared to pre-burn data. We did not compare or make conclusions about differences between burned and reference streams within 2002 specifically due to the fact that only one reference stream was sampled. However,

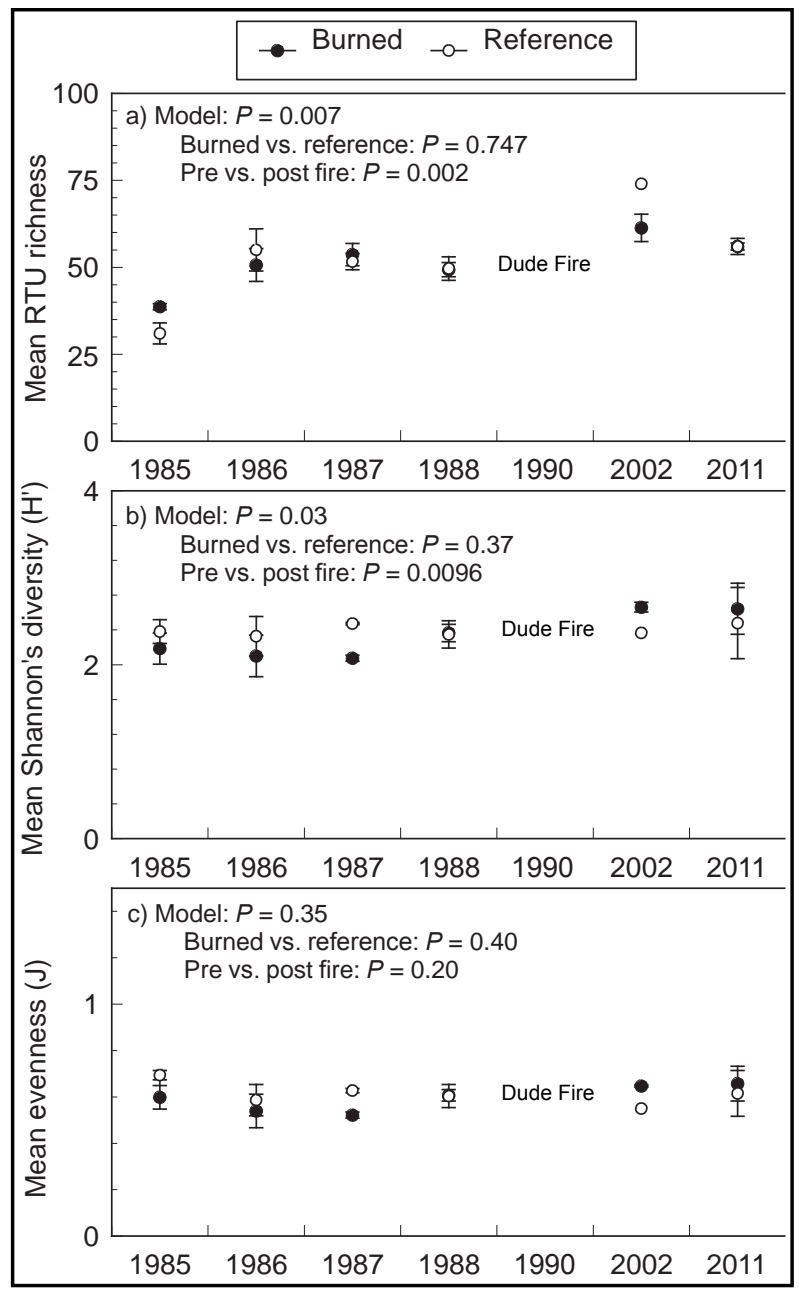

Figure 5. Recognizable Taxonomic Unit (RTU) richness, Shannon's diversity $\left(H^{\prime}\right)$, and evenness for macroinvertebrate communities through time. Error bars represent standard errors of the mean. The Dude Fire occurred in 1990 and resulted in the near elimination of macroinvertebrate communities within burned streams based on data published by Rinne (1996). ANOVA $\alpha=0.05$. we did include the data for that reference stream (Pine Creek) to give some context. By 2011, analysis of richness, abundance, diversity $\left(H^{\prime}\right)$, and evenness $\left(J^{\prime}\right)$ showed no differences between burned and reference streams $(P=$ $0.52,0.65,0.57$, and 0.60 , respectively; $F_{1,13}$; Figure 7). Comparison of individual orders in 2011 showed that mean percent abundances were not different between burned and reference streams (Figure 8; all $P>0.05$ ). Similarly, there were no differences in functional feeding group mean percent abundances between burned and reference streams in 2011 (Figure 9; all $P>0.05$ ).

\section{Canopy Closure and Temperature.}

Canopy closure for streams within the fire perimeter was lower when compared to reference conditions (Table 3; $P=0.0007$ ). Average canopy closure for burned streams was $62.6 \%$, ranging from $54.3 \%$ to $73.7 \%$, compared to reference streams, which averaged $87.1 \%$, ranging from $81.9 \%$ to $91.9 \%$, an average reduction of $28.1 \%$. Due to reduced canopy cover and high occurrence of bedrock within the channel, Dude Creek was, on average, $>2{ }^{\circ} \mathrm{C}$ warmer during the 2011 summer period. During one of the hottest days of 2011, the water temperature peaked at 26.9C in Dude Creek, while reference streams of Pine and Horton creeks were $19.5^{\circ} \mathrm{C}$ and $19.0^{\circ} \mathrm{C}$, respectively (Figure 10 ).

\section{Stream Chemistry and Benthic Algae}

Concentrations of chloride $(P=0.04)$, nitrate $(P=0.04)$, orthophosphate $(P=0.05)$, sulfate $(P=0.04)$, potassium $(P=0.01)$, and magnesium $(P=0.01)$ were all lower in burned streams compared to reference streams (Table 3). Comparison of benthic algae in 2011 from multiple sources, including those from gravel, rock, silt, wood, and periphyton, did not show a difference in chlorophyll $a$ between burned and references streams (Table 3: $P=0.53)$. 


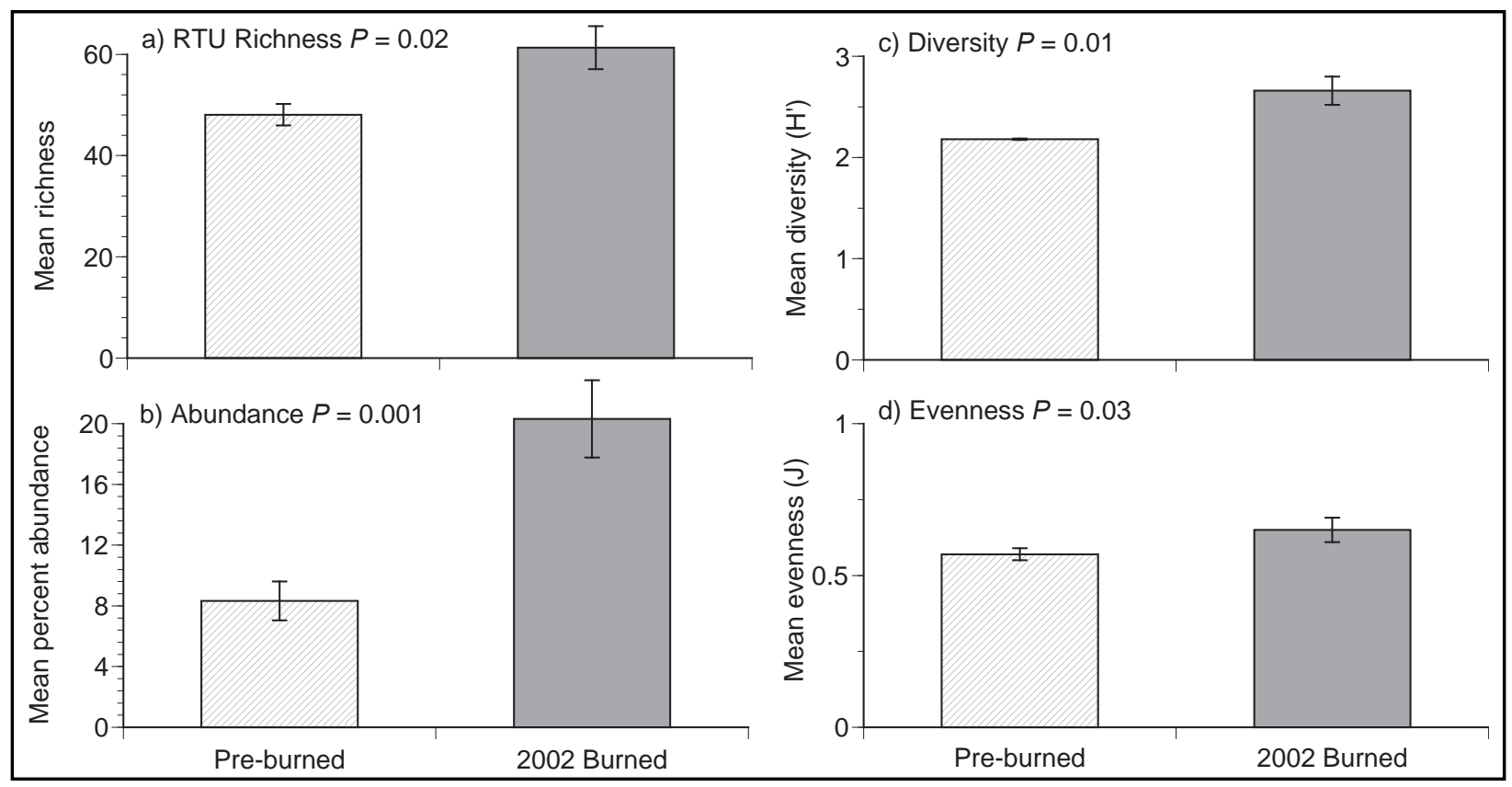

Figure 6. Recognizable Taxonomic Unit (RTU) richness, Shannon's diversity $\left(H^{\prime}\right)$, and evenness for macroinvertebrate communities within streams prior to the fire and in 2011 after being impacted by the Dude Fire. Error bars represent standard errors of the mean. $\alpha=0.05$.
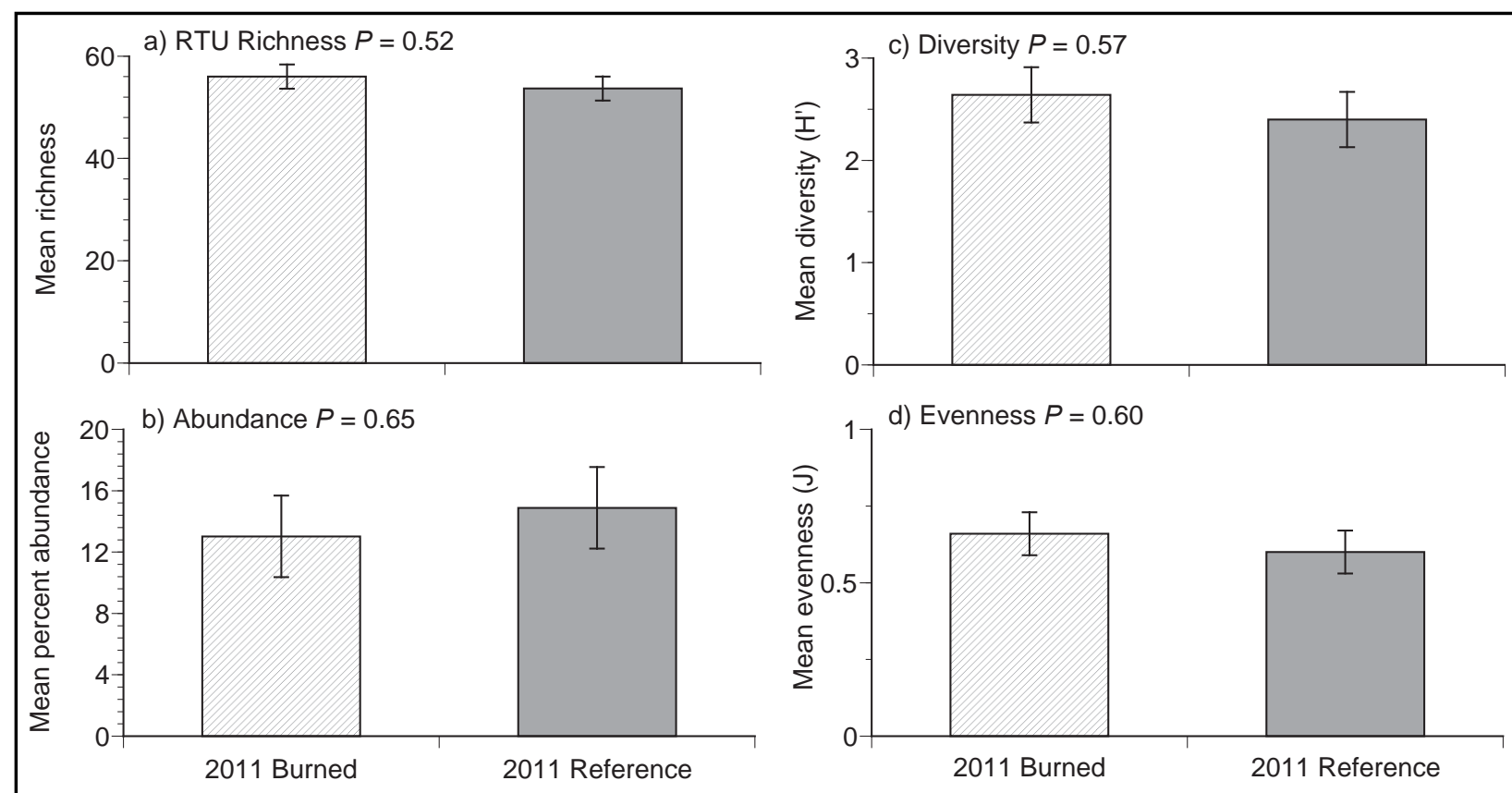

Figure 7. Recognizable Taxonomic Unit (RTU) richness, Shannon's diversity $\left(H^{\prime}\right)$, and evenness for macroinvertebrate communities within burned and reference streams in 2011. Error bars represent standard errors of the mean. $\alpha=0.05$. 

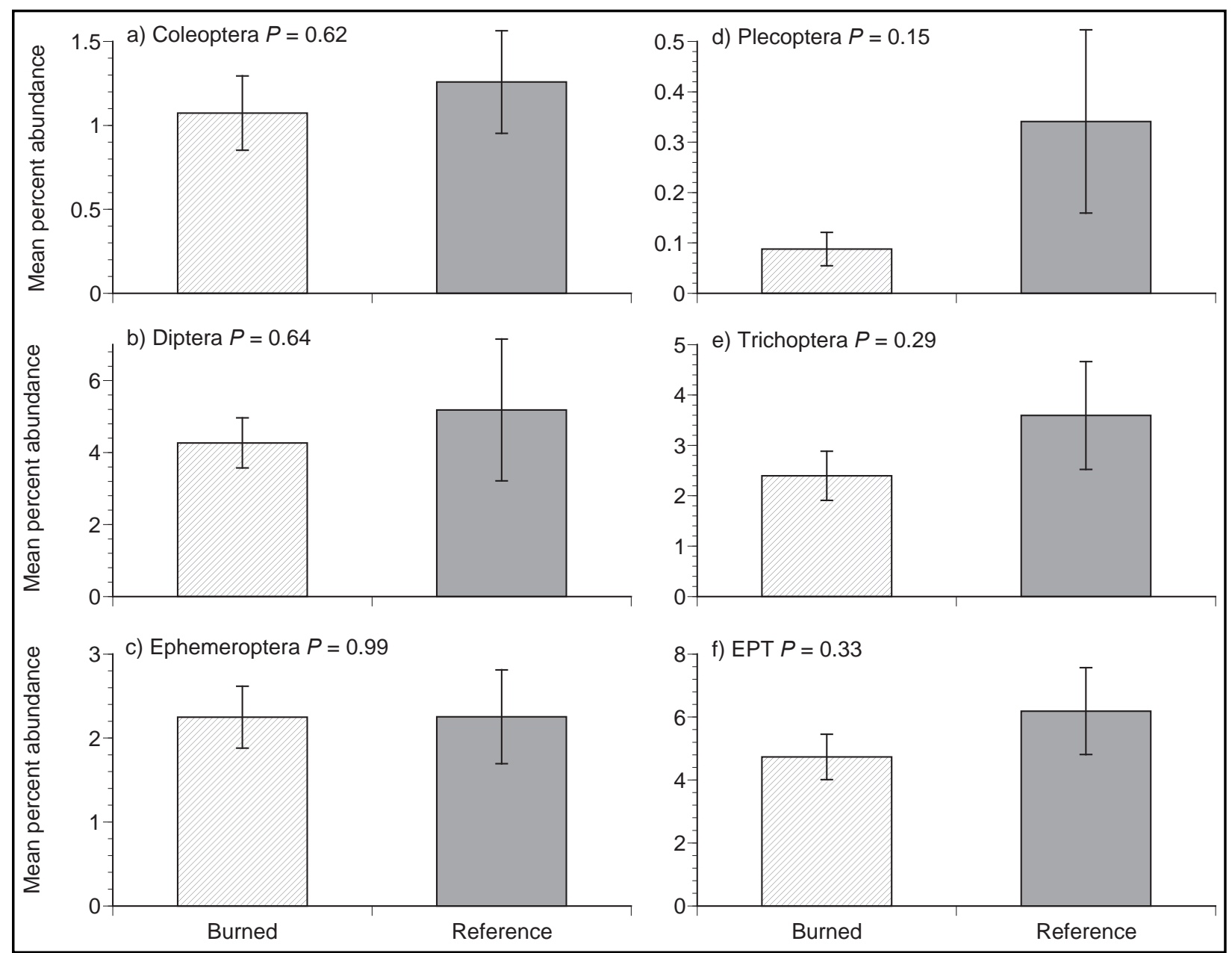

Figure 8. Mean percent abundance for selected macroinvertebrate orders within burned and reference streams in 2011. Error bars represent standard errors of the mean. $\alpha=0.05$.

\section{DISCUSSION}

The results of this study suggest that burned streams continue to have lower nutrient concentrations, less canopy closure, and, in the case of Dude Creek, higher water temperatures than reference streams after 21 years of recovery. The recovery of stream systems impacted by wildfire is closely related to the stability of the stream channel (Arkel et al. 2010, Goode et al. 2012) and recovery of the terrestrial habitat (Minshall et al. 1989, Minshall et al. 2001b, Mihuc and Minshall 2005, Vieira et al. 2011). Within a naturally balanced stream channel, an equilibrium between erosion and deposition exists that forms and maintains the stream channel (Leopold 1994). Disruption of this balance by vegetation-altering wildfire can change the timing and input of sediment into stream channels, causing detrimental effects on fish and aquatic macroinvertebrates (Goode et al. 2012).

The geomorphology survey results demonstrate that an overall loss of sediment and channel incision occurred in the years following the fire, particularly within Dude Creek. The survey efforts captured an interesting timeline of events following fire. Beginning with the period from 1990 to 1992, transects on Dude Creek both aggraded and degraded at a fairly high rate. This suggests that large amounts of bedload had been displaced by a 

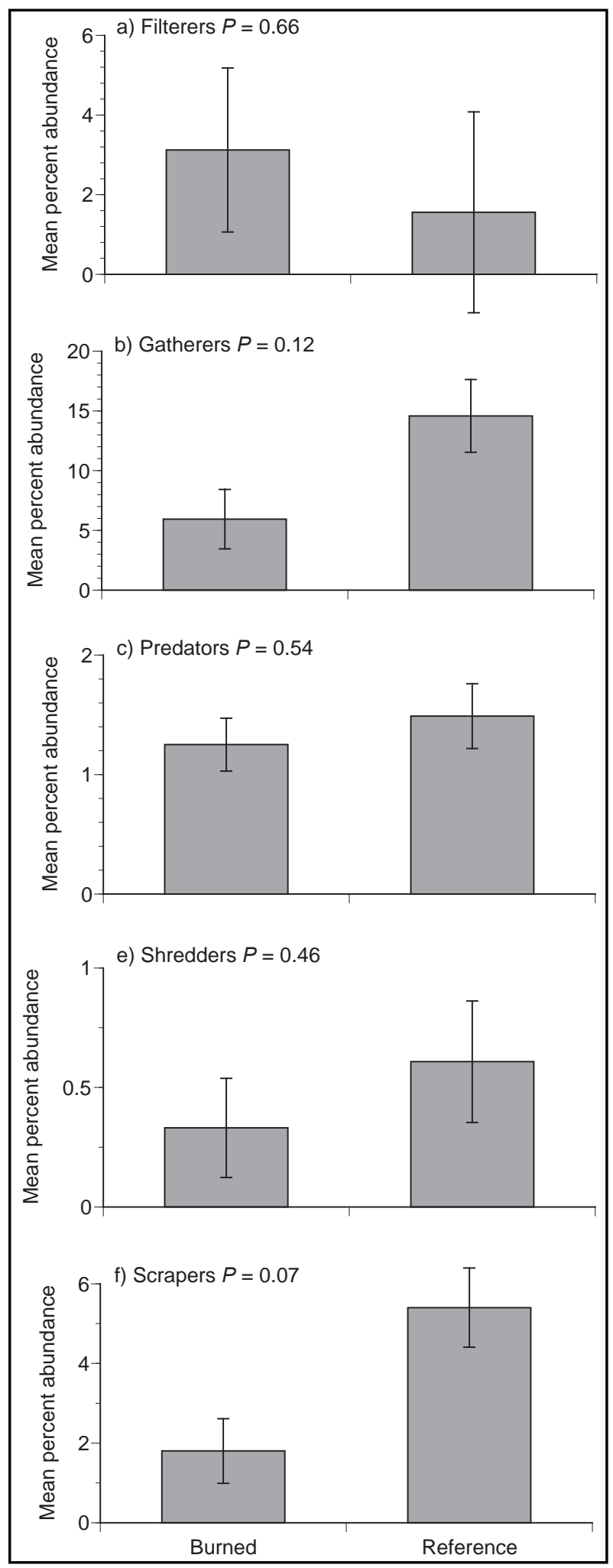

Figure 9. Mean percent abundance for functional feeding groups within burned and references streams in 2011. Error bars represent standard errors of the mean. $\alpha=0.05$. flooding event in 1991 and were beginning to make their way down the stream channel. Then, in 1993 and again in 1995, major flooding events occurred within the region. These severe flooding events were most likely magnified by the effects of the fire, namely loss of vegetative cover, and they further destabilized the stream channels leading to significant sediment loss, which greatly changed the physical stream environment.

A subsequent flooding event in 1998 appears to have also impacted Dude Creek with further sediment loss but only had minimal effects on Ellison and Bonita creeks. From 2001 to 2011, even though several regional flooding events occurred during this period, transects surveyed appeared to have become more stable. This suggests that most of the significant losses of sediment from the headwater portions of these streams appear to have occurred within the first decade after the fire.

While it appears that the rate of incision slowed by 2001 within the impacted streams in this study, it does not mean that losses in sediment from the streams have been recovered, nor does it mean that the sediment currently in the channel has become stable. It simply indicates that the accumulation of sediment is nearing a point of equilibrium to the amount of sediment lost within these systems. Physical stream channel structure such as bank formation and streamside vegetation (e.g., sedges, rushes, bryophytes), which are both indicators of sediment stability, continue to be absent in places and will most likely take decades to recover fully. In addition, the results of the pebble count data suggest that the dominant particle sizes within Dude and Ellison creeks continued to shift over the period from 2001 to 2011 and supports the view that the bedloads within these two streams remain in flux.

The physical degradation that occurred following fire contributed to the alteration of the community structure of macroinvertebrates within the burned streams. Sampling conducted immediately after the fire indicated that 
Table 3. ANOVA results for stream nutrients and environmental variables taken in 2011 and 2012. Bold values indicate significance at $\alpha=0.05$

\begin{tabular}{|c|c|c|c|c|c|c|}
\hline & $\begin{array}{c}\text { Burned } \\
\text { mean }\end{array}$ & $\begin{array}{c}\text { Unburned } \\
\text { mean }\end{array}$ & Burned SE & $\begin{array}{c}\text { Unburned } \\
\text { SE }\end{array}$ & $F$ ratio & $P$-value \\
\hline Chloride (mg L-1) & 0.49 & 0.82 & 0.12 & 0.10 & 4.75 & 0.04 \\
\hline Nitrate (mg L $\left.{ }^{-1}\right)$ & 0.08 & 0.16 & 0.03 & 0.02 & 4.94 & 0.04 \\
\hline O-Phosphate (mg L-1) & 0.08 & 0.12 & 0.01 & 0.01 & 4.71 & 0.05 \\
\hline Sulfate (mg L ${ }^{-1}$ ) & 1.68 & 5.37 & 1.59 & 1.30 & 4.91 & 0.04 \\
\hline Sodium (mg L-1) & 1.77 & 2.00 & 0.14 & 0.11 & 1.70 & 0.20 \\
\hline Potassium (mg L ${ }^{-1}$ ) & 1.33 & 1.85 & 0.15 & 0.12 & 7.13 & 0.01 \\
\hline Magnesium (mg L-1) & 17.61 & 27.55 & 2.88 & 2.35 & 7.13 & 0.01 \\
\hline Calcium (mg L-1) & 130.59 & 116.37 & 6.22 & 5.10 & 3.14 & 0.09 \\
\hline Chlorophyll $a\left(\mu \mathrm{g} \mathrm{L}^{-1}\right)$ & 446.48 & 517.55 & 86.21 & 70.39 & 0.41 & 0.53 \\
\hline Canopy cover (\%) & 62.56 & 87.07 & 3.61 & 2.94 & 20.94 & 0.0007 \\
\hline Flow $\left(\mathrm{m}^{3} \mathrm{sec}^{-1}\right)$ & 0.41 & 2.15 & 0.32 & 0.26 & 17.77 & 0.0003 \\
\hline
\end{tabular}

macroinvertebrates were virtually wiped out (Rinne 1996). However, by 2002, overall species richness and diversity both increased post fire compared to pre-fire levels. These results are most likely due to the stabilization of instream habitat following flooding events as well as increases in resources that support aquatic species such as algae growth resulting from an increase in sunlight reaching the stream channel.

By 2011, measures of richness, abundance, diversity, and Pielou's evenness in burned streams were not different from reference streams, suggesting that the macroinvertebrate communities appear to have returned to reference conditions. While many biotic and abiotic factors contribute to the variability in macroinvertebrate communities from year to year, Vieira et al. (2004) also noted an increase in species richness several years following the impacts of wildfire and subsequent flooding events following the Dome Fire in New Mexico. They similarly concluded that the recovery of species richness is closely tied to the pattern of hydrologic disturbance following fire, noting that the increase in richness to above pre-fire conditions only occurred after the risk of flash flooding events abated.
Following the fire, levels of stream nutrients and discharge most likely increased due to the removal of vegetation and the increased input of ash into the stream channel (Minshall et al. 1997). However, 21 years later, stream nutrients and discharge levels were lower than reference levels. In some cases, discharge and nutrient levels fall back to below pre-disturbance levels (Likens et al. 1970). The mechanisms for this process involve many factors, but one of the most important is related to alteration of the riparian and upland vegetation condition.

In 2011, the riparian canopy closure across burned streams averaged just over $28 \%$ less than on reference streams. The reduction in riparian woody species cover directly reduces the amount of organic leaf litter inputs into the channel, decreasing a key source of stream nutrients. It also increases the amount of solar radiation hitting the stream channel, increasing stream temperatures and accelerating the loss of water in the stream channel to evaporation (Figure 11).

Additionally, the loss of much of the organic soil layer and the conversion from a pine-oak to an oak-manzanita vegetation type across much of the upland habitat could be 


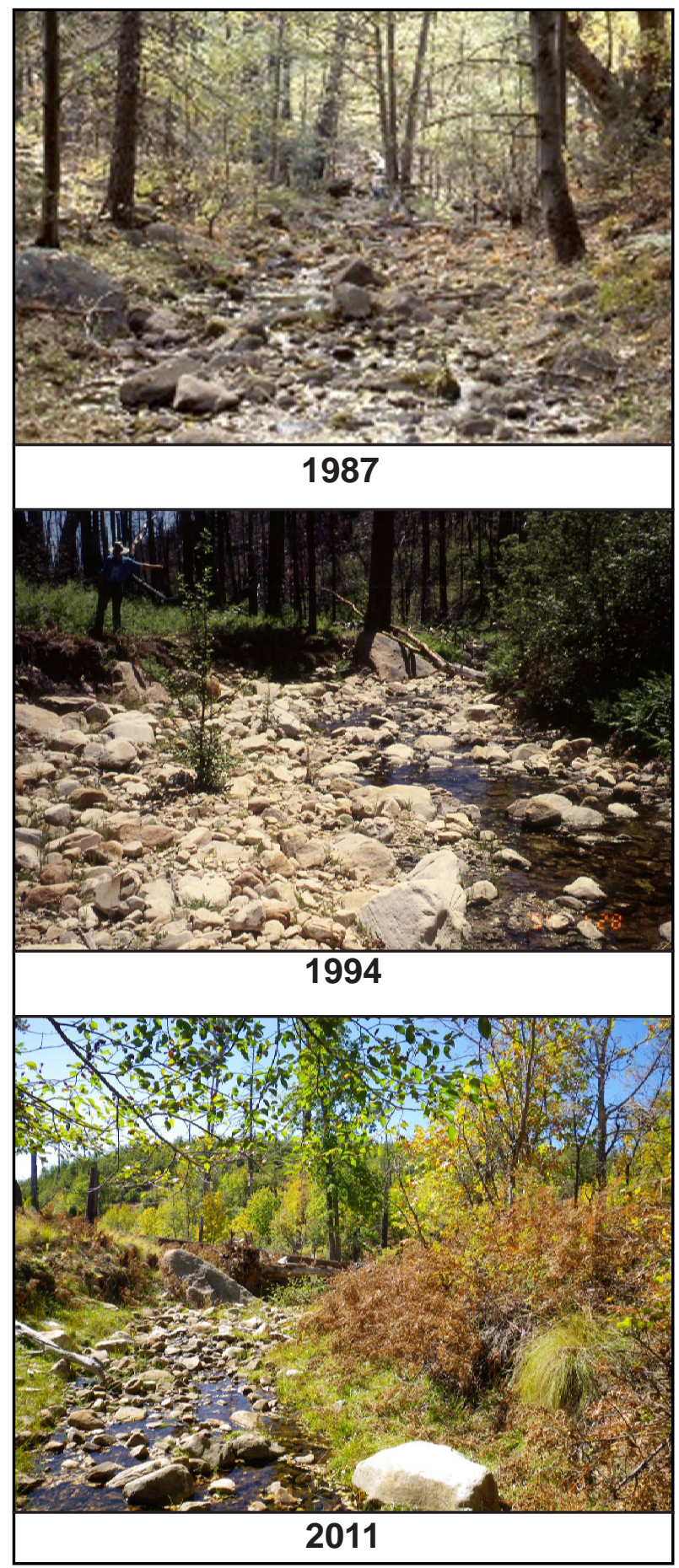

Figure 10. Change in Ellison Creek over time. In 1988 (pre fire), the channel was covered by a dense riparian canopy and the channel was defined by gradual streambanks. Flooding after the fire created erosion resulting in steep streambanks (left side of picture) and the loss of riparian canopy increased sunlight exposure within the channel. By 2011, the riparian canopy had yet to recover. further impacting the input of nutrients and movement of water from the uplands into the stream channels (Leonard et al. 2015). The regrowth of upland vegetation species in the 21 years following the fire increases the uptake of available nutrients within the soil and decreases the input into the stream channel (Likens et al. 1970). The loss of the organic soil layer reduces the transfer of soil nutrients into the stream channel and could also be altering the level of base flow discharge in the burned streams, particularly during the summer months when temperatures and evapotranspiration are at their highest (Hicks et al. 1991).

The organic soil layer serves to regulate base flow conditions by temporarily storing infiltrating rainwater, which is then slowly released into headwater stream systems (Hewlett 1961). Without the organic soil layer, precipitation that falls within the watershed quickly enters the channel during runoff events and moves downstream (DeBano et al. 1998, Neary and Leonard 2015). As a result, base flow rates of streams following landscape-scale disturbance events can decrease (Neary et al. 2005). If this holds true for the Dude Fire, it could be true of other much larger fires in the region, such as the Rodeo-Chediski Fire, Cerro Grande Fire, Wallow Fire, etc. Further research is need to determine whether base flow rates and nutrient inputs into headwater streams region-wide have been diminished after these large, high-severity wildfire events and what their long-term influence on stream productivity might be.

Finally, we found that the combination of the decrease in canopy closure and presence of exposed bedrock substrate within Dude Creek was contributing to increased water temperatures. Prior to the fire, all the streams in this study were considered habitats for salmonid fishes. Based on this fact, native Gila trout (Oncorhynchus gilae Miller, 1950) was reintroduced into Dude Creek following the fire under the Gila Trout Recovery Plan (Pittenger 2002), with the assumption that the stream 


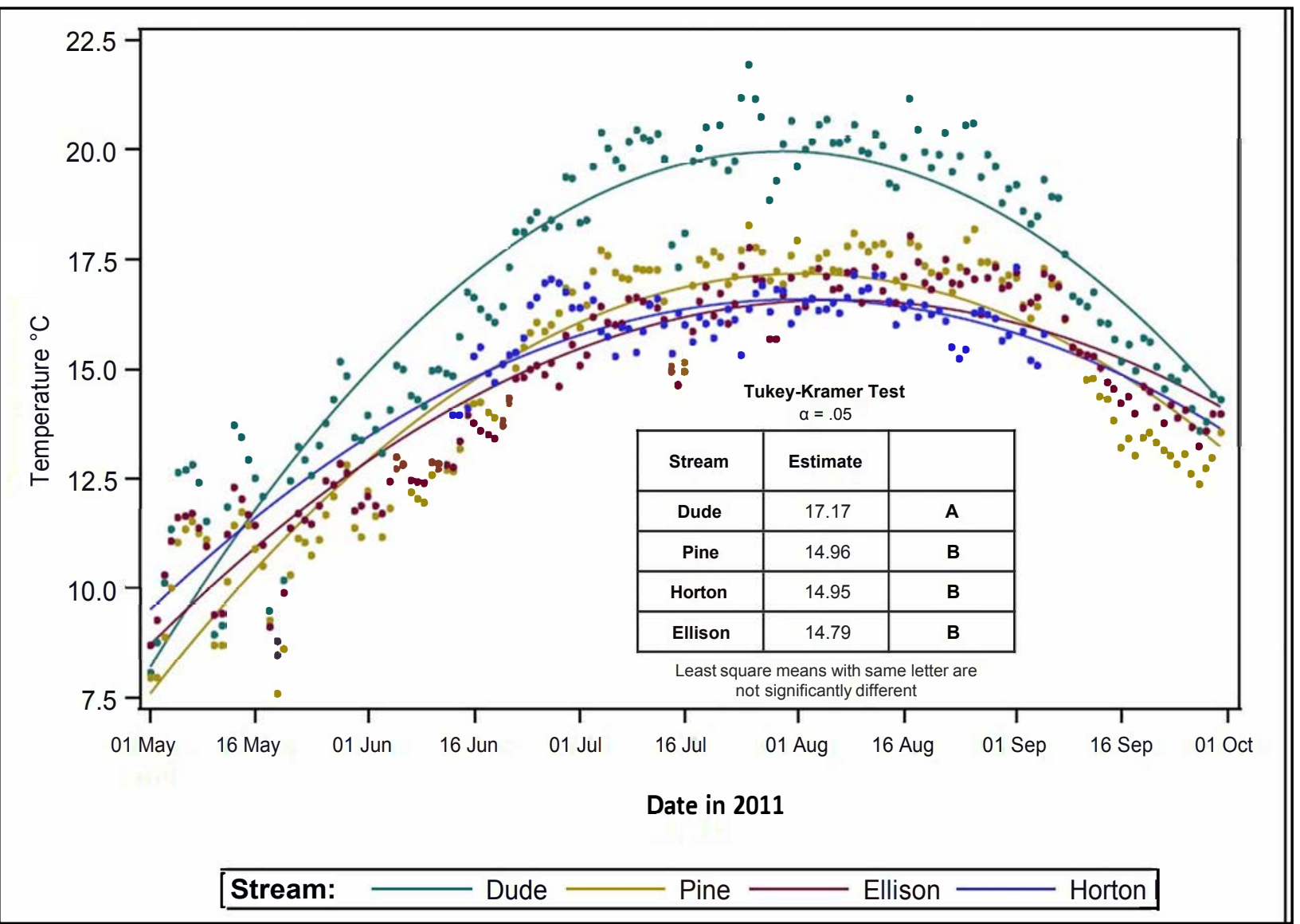

Figure 11. Average daily stream temperatures during the summer of 2011 across burned streams (Dude and Ellison) and reference streams (Pine and Horton). Bonita Creek was excluded due to equipment failure.

would still provide suitable habitat for salmonids. Stocking occurred from the late 1990s to early 2000s. Unfortunately, these efforts ultimately proved unsuccessful (Kline and Carter 2011), most likely due to a shift to higher water temperatures following the fire.

As with other closely related salmonid species, stream temperatures in excess of $20^{\circ} \mathrm{C}$ are considered unfavorable during various stages of the Gila trout's life cycle (Alcorn 1976, Lee and Rinne 1980). A decade later, stream temperatures in Dude Creek continued to average in excess of $20^{\circ} \mathrm{C}$ over several weeks during the summer of 2011 and reached nearly $27^{\circ} \mathrm{C}$ on the warmest day of the year. This supports the concept that alteration of thermal regimes within stream channels following wildfire events can be a driving force in the distribution, abundance, growth, and persistence of aquatic species (Isaak et al. 2010).

\section{CONCLUSIONS}

The loss of vegetation and post-fire flooding events following the high-severity Dude Fire resulted in long-lasting changes in channel condition of impacted streams. Measures of macroinvertebrate community health, including species richness and diversity, were altered up to a decade following the fire, and impacts of environmental variables such as stream temperature and chemistry continued to differ from reference conditions over two decades later. These results suggest that the influence of high-severity wildfire on headwa- 
ter streams is long lasting. The changes in biotic and physical conditions have made these unique ecosystems even more vulnerable to elevated temperatures in an era of climatic uncertainty. It will require further regrowth of the upland and riparian vegetation, as well as the continued stabilization of stream sediment, for impacted streams to the fully recover (Huxel and McCann 1998, Mihuc and Minshall 2005, Goode et al. 2012)—a process that could take several more decades.

Previous studies have established the positive connection between periods of drought and active fire seasons in the Southwest (Westerling and Swetnam 2003). The influence of climate change in the Southwest is predicted to be significant (Cook et al. 2015), with more extreme occurrences of El Niño and La Niña weather patterns likely (Intergovernmental Panel on Climate Change 2014), leading to intense drought conditions contrasted with sporadic, high-intensity winter precipitation events. Combined with the accumulation of fuels across the landscape due to suppression of wildfire in the last century, these factors suggest that there could be an increase in large, high-severity wildfires followed by large flooding events. Thus, the Southwest may expect more significant ecosystem disturbances like those observed in this study.

The findings of this study agree with the results of other studies, which suggest that the threats posed to headwater stream systems by severe wildfire events are considerable (Minshall et al. 1989, Goode et al. 2012). Reduction in both upland and riparian fuels through the use of prescribed fire and other methods, in order to lessen the likelihood of a high-severity wildfire occurring, has been shown to have minimal, short-term impacts on biotic function (Beche et al. 2005, Stephan et al. 2012). Efforts to manage the levels of fuel loading across the landscape with the ultimate goal of avoiding future catastrophic wildfire events are strongly supported by this study.

\section{ACKNOWLEDGEMENTS}

The authors would like to acknowledge A. Medina and J. Rinne for sharing their wisdom and access to legacy datasets. Thanks are also due to T. Whitham and J. Shannon for their guidance during the research. T. Leonard is gratefully acknowledged for her assistance and support in digitizing macroinvertebrate and photographic records. A big thanks also goes to the field crew: M. Determan, F. Walter, and M. Leonard. R. Crawford, A. Arkowitz, and C. Barrett also contributed to the study and their insights are appreciated. Support from the USDA Forest Service, Rocky Mountain Research Station; Tonto National Forest, and Northern Arizona University College of Engineering, Forestry, and Natural Sciences was instrumental in the successful completion of the study.

\section{LITERATURE CITED}

Adams, M.A. 2013. Mega-fires, tipping points and ecosystem services: managing forests and woodlands in an uncertain future. Forest Ecology and Management 294: 250-261. doi: 10.1016/j.foreco.2012.11.039

Alcorn, S.R. 1976. Temperature tolerances and upper lethal limits of Salmo apache. Transactions of the American Fisheries Society 105: 294-295. doi: 10.1577/1548-8659 (1976)105<294:TTAULL>2.0.CO;2 
Amaranthus, M., H. Jubas, and D. Arthur. 1989. Stream shading, summer streamflow and maximum water temperature following intense wildfire in headwater streams. USDA Forest Service General Technical Report PSW-109, Pacific Southwest Research Station, Berkeley, California, USA.

Arkle, R.S., D.S. Pilliod, and K. Strickler. 2010. Fire, flow and dynamic equilibrium in stream macroinvertebrate communities. Freshwater Biology 55: 299-314. doi: 10.1111/ j.1365-2427.2009.02275.x

Ball, B.A., J.S. Kominoski, H.E. Adams, S.E. Jones, E.S. Kane, T.D. Loecke, W.M. Mahaney, J.P. Martina, C.M. Prather, T.M.P Robinson, and C.T. Solomon. 2010. Direct and terrestrial vegetation-mediated effects of environmental change on aquatic ecosystem processes. American Institute of Biological Sciences 60: 590-601. doi: 10.1525/bio.2010.60.8.5

Bêche, L.A., S.I. Stephens, and V.H. Resh. 2005. Effects of prescribed fire on a Sierra Nevada (California, USA) stream and its riparian zone. Forest Ecology and Management 218: 37-59. doi: 10.1016/j.foreco.2005.06.010

Bevenger, G.S., and R.M. King. 1995. A pebble count procedure for assessing watershed cumulative effects. USDA Forest Service Research Paper RM-RP-319, Rocky Mountain Forest and Range Experiment Station, Fort Collins, Colorado, USA.

Burton, T.A. 2005. Fish and stream habitat risks from uncharacteristic wildfire: observations from 17 years of fire-related disturbances on the Boise National Forest, Idaho. Forest Ecology and Management 211: 140-149. doi: 10.1016/j.foreco.2005.02.063

Cannon, S.H., J.E. Gartner, R.C. Wilson, J.C. Bowers, and J.L. Laber. 2008. Storm rainfall conditions for floods and debris flows from recently burned areas in southwestern Colorado and southern California. Geomorphology 96: 250-269. doi: 10.1016/j.geomorph.2007.03.019

Cook, B.I., T.R. Ault, and J.E. Smerdon. 2015. Unprecedented 21st century drought risk in the American Southwest and Central Plains. Science Advances: 1-7. doi: 10.1126/ sciadv.1400082

Cuffney, T.F., M.D. Bilger, and A.M. Haigler. 2007. Ambiguous taxa: effects on the characterization and interpretation of invertebrate assemblages. Journal of the North American Benthological Society 26(2): 286-307. doi: 10.1899/0887-3593(2007)26[286:ATEOTC]2.0.CO;2

Cummins, K.W., and R.W. Merritt, editors. 2008. An introduction to the aquatic insects of North America. Kendall Hunt Publishing, Dubuque, Iowa, USA.

Davis, J.C., G.W. Minshall, C.T. Robinson, and P. Landres. 2001. Monitoring wilderness stream ecosystems. USDA Forest Service General Technical Report RMRS-GTR-70, Rocky Mountain Research Station, Ogden, Utah, USA.

DeBano, L.F., D.G. Neary, and P.F. Ffolliott. 1998. Fire effects on ecosystems. John Wiley \& Sons, Inc., New York, New York, USA.

Dunham, J.B., M.K. Young, R.E. Gresswell, and B.E. Rieman. 2003. Effects of fire on fish populations: landscape perspectives on persistence of native fishes and nonnative fish invasions. Forest Ecology and Management 178: 183-196. doi: 10.1016/S0378-1127(03)00061-6

Dunham, J.B., A.E. Rosenberger, C.H. Luce, and B.E. Rieman. 2007. Influences of wildfire and channel reorganization on spatial and temporal variation in stream temperature and the distribution of fish and amphibians. Ecosystems 10: 335-346. doi: 10.1007/s10021-007-9029-8

Eaton, J.G., and R.M. Scheller. 1996. Effects of climate warming on fish thermal habitat in streams of the United States. Limnology and Oceanography 41: 1109-1115. doi: 10.4319/ lo.1996.41.5.1109 
Fuller, J.E., P.K. House, and P.A. Pearthree. 1996. An assessment of the paleoflood hydrology methodology: analysis of the 1993 flood on Tonto Creek, central Arizona. Report No. 96-12. Arizona Geological Survey, Tucson, Arizona, USA.

Goode, J.R., C.H. Luce, and J.M. Buffington. 2012. Enhanced sediment delivery in a changing climate in semi-arid mountain basins: implications for water resource management and aquatic habitat in the northern Rocky Mountains. Geomorphology 139: 1-15. doi: 10.1016/j. geomorph.2011.06.021

Hall, S.J., and D. Lombardozzi. 2008. Short-term effects of wildfire on montane stream ecosystems in the southern Rocky Mountains: one and two years post-burn. Western North American Naturalist 68: 453-462. doi: 10.3398/1527-0904-68.4.453

Hardy, T., P. Palavi, and D. Mathias. 2005. WinXSPRO, a channel cross section analyzer, user's manual, version 3.0. USDA Forest Service General Technical Report RMRS-GTR-147, Rocky Mountain Research Station, Fort Collins, Colorado, USA.

Hewlett, J.D. 1961. Soil moisture as a source of base flow from steep mountain watersheds. Station paper 132, USDA Forest Service, Southeastern Forest Experiment Station, Asheville, North Carolina, USA.

Hicks, B.J., R.L. Beschta, and R. Harr. 1991. Long-term changes in streamflow following logging in western Oregon and associated fisheries implications. Water Resources Bulletin 27: 217-226. doi: 10.1111/j.1752-1688.1991.tb03126.x

Huntington, T.G., A.D. Richardson, K.J. McGuire, and K. Hayhoe. 2009. Climate and hydrological changes in the northeastern United States: recent trends and implications for forested and aquatic ecosystems. Canadian Journal of Forest Research 39: 199-212. doi: 10.1139/ X08-116

Huxel, G.R., and K. McCann. 1998. Food web stability: the influence of trophic flows across habitats. The American Naturalist 152: 460-469. doi: 10.1086/286182

Ingram, R.S., C. Dils, C. Gobar, D. Raspberry-Gobar, S. Lamoreux, G. Loomis, N. Ambos, J. Mercer, R. Uberuaga, D. Pollock, M. Orr, D. Carrothers, H, Apfel, and R. Lucas. 1991. Dude Fire Long Range Rehabilitation Implementation and Monitoring Plan. US Department of Agriculture, US Forest Service, Tonto National Forest, Phoenix, Arizona, USA.

Intergovernmental Panel on Climate Change. 2014. Climate Change 2014: Mitigation of Climate Change. Contribution of Working Group III to the Fifth Assessment Report of the Intergovernmental Panel on Climate Change. In: O. Edenhofer, R. Pichs-Madruga, Y. Sokona, E. Farahani, S. Kadner, K. Seyboth, A. Adler, I. Baum, S. Brunner, P. Eickemeier, B. Kriemann, J. Savolainen, S. Schlömer, C. von Stechow, T. Zwickel and J.C. Minx, editors. Cambridge University Press, England, United Kingdom, and New York, New York, USA.

Isaak, D.J., C.H. Luce, B.E. Rieman, D.E. Nagel, E.E. Peterson, D.L. Horan, S. Parkes, and G.L. Chandler. 2010. Effects of climate change and wildfire on stream temperatures and salmonid thermal habitat in a mountain river network. Ecological Applications 20: 1350-1371. doi: 10.1890/09-0822.1

Kashian, D.M., W.H. Romme, D.B. Tinker, M.G. Turner, and M.G. Ryan. 2013. Postfire changes in forest carbon storage over a 300-year chronosequence of Pinus contorta-dominated forests. Ecological Monographs 83: 49-66. doi: 10.1890/11-1454.1

Kenward, M.G. and J.H. Roger. 1997. Small sample inference for fixed effects from restricted maximum likelihood. Biometrics 53: 983-997. doi: 10.2307/2533558

Kline, S.J., and J.M. Carter. 2011. Gila trout recovery status and Pinaleno project update. <http://www.aztu.org/Kline_and_Carter_2011_Gila_trout_recovery_status_and_Pinaleno_ project_update.pdf>. Accessed 9 November 2011. 
Kramer, C. Y. 1956. Extension of multiple range tests to group means with unequal numbers of replications. Biometrics 12: 307-310. doi: 10.2307/3001469

Lee, R.M., and J.N. Rinne. 1980. Critical thermal maxima of five trout species in the southwestern United States. Transactions of the American Fisheries Society 109: 632-635. doi: 10.1577/1548-8659(1980)109<632:CTMOFT>2.0.CO;2

Leonard, J.M., A.L. Medina, D.G. Neary, and A. Tecle. 2015. The influence of parent material on vegetation response 15 years after the Dude Fire, Arizona. Forests 6: 613-635. doi: 10.3390/f6030613

Leopold, L.B. 1994. A view of the river. Harvard University Press, Cambridge, Massachusetts, USA.

Likens, G.E., F.H. Bormann, N.M. Johnson, D. Fisher, and R.S. Pierce. 1970. Effects of forest cutting and herbicide treatment on nutrient budgets in the Hubbard Brook watershed-ecosystem. Ecological Monographs 40: 23-47. doi: 10.2307/1942440

McKenzie, D., Z. Gedalof, D.L. Peterson, and P. Mote. 2004. Climatic change, wildfire, and conservation. Conservation Biology 18: 890-902. doi: 10.1111/j.1523-1739.2004.00492.x

Medina, A.L., and R.K. Royalty. 2002. A 12-year, post-wildfire geomorphologic evaluation of Ellison Creek, central Arizona. Hydrology and Water Resources in Arizona and the Southwest 32: 77-82.

Mihuc, T., and G.W. Minshall. 2005. The trophic basis of reference and post-fire stream food webs 10 years after wildfire in Yellowstone National Park. Aquatic Sciences 67: 541-548.

Minshall, G.W. 2003. Responses of stream benthic macroinvertebrates to fire. Forest Ecology and Management 178: 155-161. doi: 10.1016/S0378-1127(03)00059-8

Minshall, G.W., J.T. Brock, and J.D Varley. 1989. Wildfires and Yellowstone's stream ecosystems. Bioscience 39: 707-715. doi: 10.2307/1311002

Minshall, G.W., C.T. Robinson, T.V. Royer, and S.R. Rushforth. 1995. Benthic community structure in two adjacent streams in Yellowstone National Park five years after the 1988 wildfires. The Great Basin Naturalist 55: 193-200.

Minshall, G.W., C.T. Robinson, and D.E. Lawrence. 1997. Postfire responses of lotic ecosystems in Yellowstone National Park, USA. Canadian Journal of Fisheries and Aquatic Sciences 54: 2509-2525. doi: 10.1139/f97-160

Minshall, G.W., J.T. Brock, D.A. Andrews, and C.T. Robinson. 2001a. Water quality, substratum and biotic responses of five central Idaho (USA) streams during the first year following the Mortar Creek Fire. International Journal of Wildland Fire 10: 185-199. doi: 10.1071/ WF01017

Minshall, G.W., C.T. Robinson, D.E. Lawrence, D.A. Andrews, and J.T. Brock. 2001b. Benthic macroinvertebrate assemblages in five central Idaho (USA) streams over a 10-year period following disturbance by wildfire. International Journal of Wildland Fire 10: 201-213. doi: 10.1071/WF01018

Minshall, G.W., T.V. Royer, and C.T. Robinson. 2001c. Response of the Cache Creek macroinvertebrates during the first 10 years following disturbance by the 1988 Yellowstone wildfires. Canadian Journal of Fisheries and Aquatic Sciences 58: 1077-1088. doi: 10.1139/f01-056

Moulton, S.R., II, J.L. Carter, S.A. Grotheer, T.F. Cuffney, and T.M. Short. 2000. Methods of analysis by the US Geological Survey National Water Quality Laboratory-processing, taxonomy, and quality control of benthic macroinvertebrate samples. US Geological Survey Open-File Report 00-212, Denver, Colorado, USA. 
Neary, D.G., and J.M. Leonard. 2015. Wildland fire: impacts on forest, woodland, and grassland ecological processes. Pages 35-112 in: A.J.B. Goncalves and A.A.B. Vieira, editors. Wildland fires: a worldwide reality. Nova Publishing, New York, New York, USA.

Neary, D.G., K.C. Ryan, and L.F. DeBano. 2005. Wildland fire in ecosystems: effects of fire on soils and water. USDA Forest Service General Technical Report RMRS-GTR-42-volume 4, Rocky Mountain Research Station, Fort Collins, Colorado, USA.

Oliver, A.A., M.T. Bogan, D.B. Herbst, and R.A. Dahlgren. 2012. Short-term changes in-stream macroinvertebrate communities following a severe fire in the Lake Tahoe basin, California. Hydrobiologia 694: 117-130. doi: 10.1007/s10750-012-1136-7

Oliver, I., and A.J. Beattie. 1996. Invertebrate morphospecies as surrogates for species: a case study. Conservation Biology 10: 99-109. doi: 10.1046/j.1523-1739.1996.10010099.x

Parker, J.T.C., W.C. Steinkampf, and M.E. Flynn, editors. 2005. Hydrology of the Mogollon highlands of central Arizona. US Geological Survey Scientific Investigations Report Number: 2004-5294, US Department of the Interior, Washington, D.C., USA.

Pfaff, J.D. 1993. Method 300.0 determination of inorganic anions by ion chromatography. US Environmental Protection Agency Environmental Monitoring Systems Laboratory, Cincinnati, Ohio, USA.

Pittenger, J. 2002. Gila trout recovery plan (third revision). US Fish and Wildlife Service, Albuquerque, New Mexico, USA.

Rhoades, C.C., D. Entwistle, and D. Butler. 2011. The influence of wildfire extent and severity on streamwater chemistry, sediment and temperature following the Hayman Fire, Colorado. International Journal of Wildland Fire 20: 430-442. doi: 10.1071/WF09086

Rinne, J.N. 2004. Forests, fish and fire: relationships and management implications for fishes in the southwestern USA. Pages 151-156 in: G.J. Scrimgeour, G. Eisler, B. McCulloch, U. Silins, and M. Monita, editors. Proceedings of the Forest Land-Fish Conference II-Ecosystem Stewardship through Collaboration. Natural Resources Canada, Canadian Forest Service, Edmonton, Alberta, Canada.

Rinne, J.N. 1996. Short-term effects of wildfire on fishes and aquatic macroinvertebrates in the southwestern United States. North American Journal of Fisheries Management 16: 653-658. doi: 10.1577/1548-8675(1996)016<0653:MBSTEO>2.3.CO;2

Rinne, J.N., and A.L. Medina. 1988. Factors influencing salmonid populations in six headwater streams, central Arizona, USA. Polish Archives of Hydrobiology 35: 515-532.

Rosenberg, D.M., and V.H. Resh. 1993. Freshwater biomonitoring and benthic macroinvertebrates. Chapman \& Hall, New York, New York, USA.

Rosgen, D.L. 1994. A classification of natural rivers. Catena 22: 169-199. doi: 10.1016/03418162(94)90001-9

Rugenski, A.T., and G.W. Minshall. 2014. Climate-moderated responses to wildfire by macroinvertebrates and basal food resources in montane wilderness streams. Ecosphere 5: 1-24. doi: 10.1890/ES13-00236.1

Seager, R., M. Ting, I. Held, Y. Kushnir, J. Lu, G. Vecchi, H.-P. Huang, N. Harnik, A. Leetmaa, N.-C. Lau, C. Li, J. Velez , and N. Naik. 2007. Model projections of an imminent transition to a more arid climate in southwestern North America. Science 316: 1181-1184. doi: 10.1126/science.1139601

Spencer, C.N., K.O. Gabel, and F.R. Hauer. 2003. Wildfire effects on stream food webs and nutrient dynamics in Glacier National Park, USA. Forest Ecology and Management 178: 141153. doi: 10.1016/S0378-1127(03)00058-6 
Stephan K., K.L. Kavanagh, and A. Koyama. 2012. Effects of spring prescribed burning and wildfires on watershed nitrogen dynamics of central Idaho headwater areas. Forest Ecology and Management 263: 240-252. doi: 10.1016/j.foreco.2011.09.013

Strickler, G.S. 1959. Use of the densiometer to estimate density of forest canopy on permanent sample plots. USDA Forest Service Research Note 180, Pacific Northwest Forest and Range Experiment Station, Portland, Oregon, USA.

Tronstad, L.M., J.C. Bish, R.O. Hall, and T.M. Koel. 2012. Comparing stream invertebrate assemblages before and after wildfire in Yellowstone National Park. University of Wyoming National Park Service Research Center Annual Report 35: 150-155.

US Forest Service. 1989. Southwest region terrestrial ecosystems survey of Tonto National Forest. TES Reports 1 and 2. USDA Forest Service, Southwestern Region, Phoenix, Arizona, USA.

Vieira, N.K., W.H. Clements, L.S. Guevara, and B.F. Jacobs. 2004. Resistance and resilience of stream insect communities to repeated hydrologic disturbances after a wildfire. Freshwater Biology 49: 1243-1259. doi: 10.1111/j.1365-2427.2004.01261.x

Vieira, N.K., T.R. Barnes, and K.A. Mitchell. 2011. Effects of wildfire and postfire floods on stonefly detritivores of the Pajarito Plateau, New Mexico. Western North American Naturalist 71: 257-270. doi: 10.3398/064.071.0213

Welschmeyer, N.A. 1994. Fluorometric analysis of chlorophyll $a$ in the presence of chlorophyll $b$ and pheopigments. Limnology and Oceanography 39: 1985-1992. doi: 10.4319/ lo.1994.39.8.1985

Westerling, A.L., and T.W. Swetnam. 2003. Interannual to decadal drought and wildfire in the western United States. EOS, Transactions American Geophysical Union 84(49): 545-555. doi: 10.1029/2003EO490001

Westerling, A.L., H.G. Hidalgo, D.R. Cayan, and T.W. Swetnam. 2006. Warming and earlier spring increase western US forest wildfire activity. Science 313: 940-943. doi: 10.1126/ science.1128834

Williams, A.P., C.D. Allen, C.I. Millar, T.W. Swetnam, J. Michaelsen, C.J. Still, and S.W. Leavitt. 2010. Forest responses to increasing aridity and warmth in the southwestern United States. Proceedings of the National Academy of Sciences of the United States of America 107: 21289-21294. doi: 10.1073/pnas.0914211107 